\title{
The new Portuguese law on surrogacy - The story of how a promising law does not really regulate surrogacy arrangements
}

\author{
Vera Lúcia Raposo ${ }^{1,2}$ \\ ${ }^{1}$ Faculty of Law of Macao University, Macao, China \\ 2 Faculty of Law of Coimbra University, Coimbra, Portugal
}

\begin{abstract}
Since 2006, surrogacy arrangements have been expressly forbidden within the Portuguese legal order, in any one of its forms, and in some situations, it has even been criminalised. However, since August 2016, surrogacy has been allowed under certain restrictive scenarios, providing it follows several prerequisites. In spite of this progress, the 2016 amendment to the law has not been immune to criticism. One of its most debatable aspects is the lack of the surrogate's right to regret, although it is doubtful that surrogacy contracts will be enforced against a surrogate's wishes. But the weakest point of the new law is its failure to address some of the nuclear issues of surrogacy contracts, leaving solutions either to general contract law or to the clauses stipulated by the parties. Furthermore, it is unclear which clauses are allowed and which are forbidden under the law. This study describes the content of the new Portuguese surrogacy law, exposes its main fragilities and suggests solutions for matters not covered by the law. The conclusion is that a law full of promise fails regarding the issues it is supposed to regulate.
\end{abstract}

Keywords: contracts, Portugal, right to regret, surrogate mothers

\section{THE STORY OF THE LAW}

I.1.Before artificial reproductive technique (ART) regulation

The ban on surrogacy corresponds to the traditional position of Portuguese legal scholars, existing long before the express prohibition was issued by lawmakers.

The main argument justifying this position was mostly provided by the principles of public order ('ordem publica') and morality ('bons costumes'), which have operated as limits to contractual freedom, as disposed of in article 280/1 of the Civil Code (hereafter CC). According to this statutory norm, any contract contrary to public order or offensive to morality is null and void of all effects. However, both concepts have been open to interpretation, to be determined by the judge in each specific case, and have therefore been largely dependent on the judge's worldview and values. It has generally been understood that to allow a woman to use her body to gestate a child on behalf of someone else, to dispose of her parental rights and duties and to give the child up (because the child was considered to 'belong' to the surrogate), would violate these core values (especially if there has been a monetary exchange) (Araújo, 1999).

In addition to the foregoing, by introducing a new way of regulating the offspring's status, the legal admissibility of surrogacy arrangements would violate the numerous clauses principle. This principle embodies the legal mechanisms aimed at regulating the destiny of minors, and it has historically banned any kind of contractual obligation in this regard (Oliveira, 1992). In addition, article 1982/3CC would have to be considered. Under this provision, a mother could only consent to adoption six weeks after giving birth, allowing her enough time to make a mature decision (Oliveira, 1992). Opponents of surrogacy argue that if a woman could only decide to give up a child after a certain amount of time has elapsed following birth, admaiori ad mainus, she could not decide to give up a child before birth, much less before conception.

\section{I.2.After ART regulation (Law n.32/2006)}

In 2006, Law n.32/2006 (Law n.32/2006, from 26 July, on Medically Assisted Reproduction) was enacted to regulate ART and it expressly banned surrogacy arrangements.

Article 8/2 of Law n.32/2006 (revoked version) deemed surrogacy contracts null and void of any effect (although interestingly, Article 63/5 of the Medical Deontological Code admitted medical procedures connected to surrogacy in exceptional cases). This legal solution seemed to recognise the argument that even in the absence of an express ban, surrogacy contracts violated public order and morality. However, it can also be stated that if the lawmakers felt the need the need to declare these contracts null, it was precisely because they did not violate these basic principles. Otherwise, nullity would simply have been deduced from article $280 / 2$ CC, and it would not have been necessary to further clarify it (Costa \& Lima, 2012).

The aforementioned Article 8 of Law n.32/2006 established motherhood based on the general criteria included in the Civil Code, in which delivery was the only criterion used to determine who the legal mother was. In other words, the surrogate was, under all circumstances, considered to be the mother. Therefore, even if all of the parties to the arrangement agreed with it, a surrogacy contract would, as a matter of law, always be deemed null and devoid of any effect, and the surrogate would be designated the legal mother in every case, a solution that some scholars posited constituted a kind of sanction on her.

The status of the surrogate as the legal mother, in any event, has been one of the most criticised aspects of the Portuguese solution, and some authors advocated the recognition of the contracting parents as legal parents, at least when they have both contributed with their own gametes (Ascensão, 2007; Costa \& Lima, 2012; Raposo, 2014). The aim of this rule was arguably to discourage surrogacy contracts by depriving them of any possible effect. However, the solution has led to an iniquitous outcome. Motherhood has been imposed on surrogates even when they did not want the child and were not willing to care for it, or when they simply did not have the necessary financial resources. In such cases, the child would most probably be given up for adoption (Ascensão, 2007). 
Basically, the law has only recognised the gestational criterion of motherhood, knowingly putting aside the volitional criterion, i.e., the assumption that someone wants to raise and love the child, which the contracting parents in this scenario do. Moreover, the law has also disregarded the genetic criterion, given that the rule nowadays is to disconnect the genetic contribution from the gestational one. Rarely is the surrogate the one providing the egg today. Actually, whenever possible the egg provider is the contracting mother, who then becomes the genetic mother as well. However, this biological bond has been ignored by the law, and the mother is defined as the one who gives birth, even if she has no other correspondence with the child in real life or scientifically. It has been difficult to understand why the Portuguese law has excluded the filial bond regarding gamete donors (which is certainly a reasonable solution), recognising them as merely participants in the reproductive project of someone else; but at the same time, affording a privileged status to the surrogate, even when she has no genetic bond with the child, and knowing that she frequently has no intention or desire to care for the baby.

Another objectionable aspect of the Portuguese legal regime has been the criminalisation of surrogacy contracts whenever they have involved a payment (but not when they are gratuitous), a solution criticised by many (Antunes, 2009; Dias, 2008; Reis, 2010; Costa \& Lima, 2012; Raposo, 2014). Article 31/1 of Law n.32/2006 (revoked version) stated that those participating in surrogacy arrangements might be punished with imprisonment up to two years or a fine up to 240 days. The statute used a strange and multi-significant expression: 'the ones entering into contracts' ('quem concretizar contratos') that seemed to cover both the contracting parents and the surrogate, in addition to the lawyer assisting them. The same penalty was also envisaged for those promoting paid surrogacy arrangements, usually lawyers or ART clinics. As pointed out by Costa \& Lima (2012), the expression was strange and rather ambiguous. Did it also include the medical staff eventually participating in the medical procedure? What about if the contract was signed but not actually executed; would the participants also be criminally sanctioned?

\section{THE NEW CONTENT OF LAW N.32/2006}

Since August 2016 (due to Law n.25/2016, from 22 August, that regulates access to surrogate motherhood, introducing the 3rd modification of Law n.32/2006), Law n.32/2006 (any quoted Article in this study belongs to Law n.32/2006, in its current version, unless some other law is indicated) allows surrogacy arrangements in certain specific situations, defined in quite restrictive terms: women born without a uterus, or having a serious lesion or disease of the uterus that prevents the gestation of a child, or in other justifiable clinical conditions (Article $8 / 2$ ). Surrogacy cannot be used by single gay men nor by male gay couples and both fatherhood candidates are still excluded from Article 6 . In effect, in its original version this law only allowed the use of ART by heterosexual couples, either married or in a de facto relationship (Raposo, 2007). However, in June 2016 - due to Law n.17/2006, from 20 June - it began to allow access to any woman, regardless of her civil status or sexual orientation; whereas men can only use ART if they were part of a heterosexual couple.

Further, the gametes used must come from at least one of the contracting parents, and in no situation can the surrogate contribute her oocytes (Article 8/3) - a solution obviously created to justify the exclusion of a carrier's claim to legal motherhood.
The surrogacy procedure must be approved by the entity in charge of controlling the use of reproductive techniques, the National Council of Medically Assisted Reproduction (CNPMA, Conselho Nacional de Procriação Medicamente Assistida), which renders its decision after listening to the Medical Association's opinion on a case (Article 8/4).

Surrogacy contracts cannot involve any kind of payment or donation to the surrogate, except for her actual expenses (medical care, transportation) and only to the extent that they are duly certified to by an invoice (Article 8/5).

The law does not require a specific relationship between the parties, in contrast to some of its initial drafts, which required that the surrogate and the contracting woman be relatives. However, it forbids surrogacy arrangements, whenever there is a relationship of economic dependency (for instance, a work relationship) between the parties (Article 8/6).

Article $8 / 7$ provides that a child born through a surrogacy arrangement is considered to be the child of the contracting parents, a solution that seems to apply even if the contract is invalid (CNPMA, 2016), and more than that, even if the contracting parents have committed a crime by entering into a paid contract. This is the only possible conclusion, because Article $8 / 7$ does not include any exception to this provision; nor does the law restrict this solution to valid or lawful surrogacy contracts, and it does not have special rules for criminal cases.

The surrogacy agreement must take the form of a written contract, signed by the parties involved and supervised by the CNPMA (Article 8/10). This contract is required to clarify, in accordance with the law in effect, what shall happen in the case where an unborn child is diagnosed with a malformation or a disease, or in the case of a voluntary abortion. The fact that the law foresees these two situations suggests that it enables a decision to terminate a pregnancy, even if it is not related to the health of the unborn, i.e., is based solely on the surrogate's decision, a scenario in which abortion is also permitted under Portuguese law (the so called 'abortion by request').

Article 8/11 prohibits surrogacy contracts from imposing restrictions on the surrogate's conduct or imposing rules that undermine her rights, freedoms and dignity. This item creates ambiguity over which clauses can be included in surrogacy contracts, because strictly speaking, many contractual clauses end up restricting the surrogate's rights.

If a surrogacy contract does not comply with the requirements established by Article 8 , it will be deemed null, in accordance with the general contract theory, and void of any effect (Article 8/12).

The regular demand of informed consent, imposed on any reproductive treatment, obviously applies here, although additional information is required. For this reason, Article $14 / 6$ requires that the parties be informed of the surrogate's influence on the unborn child's development.

Article 39 deals with the criminal penalties applied to behaviour related to surrogacy arrangements, although its terms are different from the revoked version. The contracting parents risk a jail sentence of up to two years or a fine of up to 240 days if they enter into a paid surrogacy contract; and a jail sentence of up to one year or a fine of up to 120 days if they enter into a non-paid surrogacy contract in violation of the legal requirements. The surrogate can also be sanctioned, although only with a fine: up to 240 days in the case of paid surrogacy contracts and up to 120 days in the case of non-paid contracts in violation of the legal requisites. The promotion of surrogacy contracts violating the legal requisites, by any 
means (for instance, by inviting the parties or by making a public announcement), is punished with imprisonment for up to two years. However, a more severe penalty applies to those who profit in some way from the promotion or participation in such surrogacy contracts, punished with jail sentence of up to five years. The combination of these various penalties shows that the legal reproach is especially important in those cases in which money is involved, and most of all when someone receives a financial benefit from surrogacy.

For a long time I have supported the legality of surrogacy contracts provided that certain requisites are complied with, such as maintaining proper legal regulation over the main issues raised by surrogacy arrangements; strict monitoring of the contract terms by a court of law or a specialised entity (for instance, the entity in charge of controlling every aspect of ART, the CNPMA); and strict adherence to the principle of free and informed consent, especially where it concerns the surrogate. The new law, although very welcome, falls short of these intents and its legal regime still raises several relevant doubts regarding the regulation of surrogacy. Therefore, lawmakers are encouraged to reformulate the existing law to address the many topics omitted in its current version.

\section{THE RIGHT TO REGRET AND CONTRACT ENFORCEABILITY}

\section{III.1.The right to regret}

One of the most widely discussed questions in surrogacy arrangements concerns the possibility of withdrawing from the surrogacy contract, usually known as the 'right to regret' (Appleton, 2011). In court, the most common form of the right to regret comes from the surrogate, when she wants to be legally designated the child's mother instead of transferring this right to the contracting parents, who want and are entitled to the child under the original agreement. However, regret can assume very different forms and it can be expressed by any of the parties to the contract (the contracting parents or the surrogate). In the case of the surrogate it can consist of a desire to terminate the pregnancy or to keep the child (typically after birth), and it can manifest at any moment during the arrangement.

Regret may become a huge and complex problem if not properly addressed, first by lawmakers and afterwards by the parties to the contracts. If some forms of the right to regret are allowed by law, it is imperative to define the way it will operate, namely, when it should be recognised. In these regards the more restrictive point of view suggests a time frame of 48 hours after birth (Perdue, 2011; CNPMA, 2016); whereas other proposals extend the right to regret by as much as 6 weeks (this time frame is the one used in the adoption regime of Portuguese law and it is also the deadline for the surrogate to provide her consent under British law, Section 54(7) of the Human Fertilisation and Embryology Act). The definition of this time lapse if very sensitive. It cannot be too long, otherwise the surrogate and the child may become more attached to each other. Alternatively, it cannot be too short or the surrogate will not have enough time to properly decide.

The possibility that the surrogate could withdraw her initial consent to the arrangement and keep the child to herself has traditionally been one of the biggest obstacles to legally recognising surrogacy. However, in the early days the surrogate was not only the gestational carrier but also the genetic mother in every case the contracting woman was unable to provide her own genetic material. The coincidence of such status obviously increased the connection between the surrogate and the child, and provided a legal (and an ethical, physiological and genetic) basis for granting her request to keep it. However, currently surrogacy procedures generally separate the gestational and genetic contributions; in other words, in a case where the contracting woman cannot use her own reproductive gametes, the oocyte is provided by a donor and not by the surrogate. This new solution reduces the connection (physical and therefore also emotional) between the surrogate and the child. Although it cannot completely annul the possibility of regret, it certainly makes it less feasible. Further, whenever the fertilised egg belongs to the contracting mother, her genetic contribution provides additional justification for her to claim the child: not only because of her right to create a family and the content of the surrogacy contract, but also because of her genetic connection with the child. The right to create a family is an expressly recognised right in almost every European Constitution, although its exact content is not clear, namely it can be discussed if the right to create a family may serve as grounds to a claim based on a surrogacy contract. However, this study will not analyse this particular question.

If the surrogate does not contribute with her own genetic material, and if she has provided her free and informed consent to the arrangement (i.e., she was fully informed of the biological effects of pregnancy and the legal consequences attached to the surrogacy contract), her right to regret should not be recognised. She is simply a carrier, and no matter how attached she may become to the child, even believing that the child is hers, the fact is that it is not her child and she is legally committed to relinquish the baby to the contracting parents, who are often the genetic parents as well.

Although the right to regret is usually discussed in terms of the surrogate, contracting parents may also have regrets and wish to terminate the contract. Their regret leads to several different consequences, most of which are also very troubling: the surrogate may get 'stuck' with a child that she never wanted, or the child may be aborted or given up for adoption in a case where the surrogate is unwilling to keep it or does not have the economic resources to raise it. Of course, a child cannot be imposed on anyone, not even its genetic parents (the same is valid for children resulting from sexual intercourse), so the contracting parents' right to regret cannot be denied as a matter of law. However, the law (and the contract) can impose severe penalties that far exceed the usual penalties for breach of contract against those who have engaged in such a complex proceeding, and in the end, have changed their minds.

\section{2. Regret in Law n.32/2006}

III.2.a) Regret from the contracting parents before delivery

Where the contracting parents are concerned, Article 14 must be taken into consideration. This is the statute pertaining to consent for the use of ART. In its n.4 the Article states that consent can be freely withdrawn until the beginning of ART therapeutic procedures. This regulation belongs to the text of the original law and has not been modified in any way by its recent amendment.

It should be noted that Portuguese lawmakers have used the expression 'beneficiaries of the techniques' to refer to people using ART, an expression that does not include the surrogate (as it is demonstrated by the fact that in some other parts of the law both expressions are used in a cumulative way: 'beneficiaries of the techniques' and 'the surrogate'). Accordingly, the quoted terms only refer to the contracting parents' consent.

The exact determination of the 'beginning of therapeutic procedures' is crucial because it defines when the contracting parents can revoke the arrangement. An analysis of informed consent forms provided by the CNPMA (although the use of those forms is not mandatory, public hospitals and private clinics have both adopted 
them) leads to the conclusion that in accordance with the CNPMA the moment to revoke consent is at uterine transference. In fact, the forms to be signed by the ones using ART as a reproductive treatment include a clause stating: 'We understand that, regardless of the number of therapeutic cycles, this consent is valid and effective until terminated by any of the couple's elements; in each course, this withdrawal may only be operated until the embryonic transference is completed.' Nonetheless, the language of the law does not provide adequate support for this clause, given that the 'beginning of therapeutic procedures', proclaimed by Article 14/4, is the first medical act to be performed, which can be, for instance, the recollection of sperm or the use of drugs aimed at inducing ovulation. In any case, the expression does not describe uterine transference, which is a procedure that takes place at a more developed stage. Therefore, either the law or the quoted clause should be modified, because currently there is a clear contradiction between them. I believe that the informed consent form provides a more reasonable solution: the law should clearly state that consent can be withdrawn until embryonic transference, following the resolution generally adopted in comparative law, and repeatedly confirmed by courts around the world.

In the case of surrogacy contracts, the crucial moment takes place even earlier, at the signing of the contact, as it would in any other contract. In effect, Article 14/4 was not created to rule surrogacy arrangements. At least, it was not intended to regulate the relationship between the contracting parents and the surrogate, but merely the relationship between the contracting parents themselves (there is no special provision to regulate this issue within the framework of surrogacy). As for relations between the contracting parents and the surrogate, the legal regime has been established (although in very general terms) by contract law, because the law that has ultimately allowed surrogacy has been totally silent on withdrawal. Thus, only contract law is applicable, and if the contracting parents experience regret after signing the contract they can be forced to pay compensation to the surrogate for patrimonial and non-patrimonial damages. I believe, however, that Article $14 / 4$ can be used by analogy to allow for the contracting parents' regret until the time of uterine transference, just as it happens in any other reproductive treatment, as long as they pay for the expenses the surrogate might have had.

Conversely, if the contracting parents experience regret after the uterine transference they are not allowed to impose their new will on the surrogate, namely, they cannot force the surrogate to abort a foetus they no longer want (but neither can they be forced to keep the child, given that any parent cannot be prevented from giving his/her child up for adoption).

III. 2.b) Regret from the surrogate before delivery The existing Portuguese law does not foresee any right to regret for the surrogate. Not even Article 14/4, which allows consent to be withdrawn until embryonic transference (as least the norm is understood in this sense), can be used here because the statute expressly refers to the 'beneficiaries of the techniques', a term the law uses to refer to the patients, which in this specific scenario are the contracting parents. This conclusion is corroborated by Article 14/6, which expressly refers to surrogacy proceedings, stating that the beneficiaries and the surrogate mother should be informed in writing about the significance of the surrogate's influence on embryo and foetal development'. This last Article shows that the law distinguishes these two types of participants and does not consider the surrogate to be one of the 'beneficiaries of the techniques'.
Nonetheless, an embryo transfer cannot take place coercively, just as a pregnancy cannot be imposed on a woman by force; so actually the surrogate can refuse embryo transfer and can also refuse to carry on with the pregnancy. However, that does not mean that this refusal is immune to legal consequences. Because Law n.32/2006 does not include any provision giving the surrogate a right to regret, even before embryonic transference her regret may be construed as a breach of contract, thereby obligating payment of compensation to her counterpart, unless strong motives justify the refusal.

However, Article 14/4 could be used hereto allow the surrogate's withdrawal before uterine transference (although also involving the payment of expenses already incurred by the contracting parents), because in practical terms the surrogate cannot be coerced into receiving the embryos in her uterus.

Another possible scenario is regret after uterine transference. Certainly, the court cannot force the surrogate to continue with a pregnancy she does not desire; however, we may wonder whether the court will require the surrogate to pay compensation for an unlawful abortion, i.e., an abortion in violation of her contractual obligations. The question is that, in the absence of a provision included in Law n.32/2006 stating differently, non-compliance with the contract is a breach, unless it is considered justifiable noncompliance. The concept of 'justifiable breach' of a surrogacy contract requires further clarification from legislators, but it can be reasonably sustained that only the surrogate's medical condition or another special circumstance that prevents her from carrying the child to term should be deemed 'justifiable'. In any case, the contract must anticipate the possibility of the surrogate's change of mind, and this might avoid the necessity for court intervention to settle the dispute.

\section{III.2.c) Regret of the contracting parents after} delivery

Law n.32/2006 does not state any possibility for the contracting parents to claim regret after delivery, and more than that, it seems that even in the presence of a null contract the contracting parents are still considered to be the legal parents, as provided in Article 8/7 (CNPMA, 2016, 8).

In particular, the law does not provide any possibility for the parents to decline to receive the child on the grounds that it was born with a severe medical condition transmitted by the surrogate or due to the surrogate's behaviour during pregnancy. Both of these circumstances are only relevant to a compensation request in a civil lawsuit (if the remaining legal requisites are fulfilled).

Therefore, the only possibility for regretful parents is to give the child up for adoption. Under such circumstances, the surrogate is not prohibited from adopting the child. Actually, adoption is the only option for the surrogate that whishes to keep the child precisely because she is not legally considered the child's mother.

\section{III.2.d) Regret of the surrogate after delivery}

The question of the surrogate's regret after delivery was widely discussed during the drafting of the law. The CNPMA proposed that the law should include a provision allowing the surrogate to declare, within 48 hours of delivery, if she wants to be considered the mother. However, such a proposal was not accepted and it was not included in the final version. Thus, the Portuguese law does not accept, under any circumstances, the regret of the surrogate after delivery, which continues to be one of the biggest targets of criticism by Portuguese scholars regarding the existing regulation (Reis, 2016).

The question (and I still do not have a proper answer for it, given that there have not been any court decisions 
yet) is how the absence of a legal right to regret will be understood in real surrogacy cases. In sum, if the surrogate does not relinquish the child to the contracting parents it is doubtful that any court order could force her to do it. One hypothesis, probably more theoretical than real, is the one in which the surrogate wants the child and the contracting parents do not. At first glance the solution seems simple because there is no actual conflict between the parties; however, the problem is that Law n.32/2006 assigns the legal status of 'parents' to the contacting parents without exception. Therefore, it seems that in this hypothetical situation the surrogate would be required to resort to the adoption process to keep the child. Nonetheless, assuming that she is not the child's genetic mother, I see no reason not to issue a court order to deliver the child, and actually the content of Law n.32/2006 provides sufficient legal grounds to justify this outcome.

III.3. The enforcement of contract law in surrogacy contracts

Whether contract law should rule surrogacy contracts in the event of a breach is a matter for discussion. Surrogacy contracts seem to be very distant from the usual affairs regulated by contract law. Nonetheless, there is no obstacle to the application of contract law, including contractual liability, to surrogacy contracts (the same is valid for other contacts also belonging to family law, such as gamete donation), even though provisions should be incorporated to better accommodate the specificities of these contracts. Because Law n.32/2006 does not contain any such provision, the only conclusion is that contract law rules surrogacy contracts in every aspect. Otherwise these contracts would exist outside of a legal framework. So, both legal doctrine legal doctrine and court rulings would be required to adapt contract law to some of the special demands of surrogacy contracts.

One of the most relevant dimensions of contract law relates to the consequences of breach and the resulting liability. A party is in violation of a surrogacy contract every time he or she does not comply with his/her contractual obligations, and this behavior is not covered by the right to regret (assuming this right is legally accepted).

As previously mentioned, Law n.32/2006 does not foresee any right to regret. De iure condendo, the law could allow both the surrogate and the contracting parents to withdraw their consent up until the uterine transference of the embryos without being in breach, provided that the expenses already incurred have been paid. I believe this solution could be applicable to surrogacy arrangements by analogy to Article $14 / 4$, as a special provision adapting contract law to surrogacy contracts. However, it is unclear whether the courts and the CNPMA would accept this interpretation. If not, it means that after signing the contract, any change of mind will be considered a violation of the surrogacy contract and the legal consequences of breach will apply, namely, the payment of damages.

Nonetheless, this specific contract cannot be enforced against a defaulting party because there is no juridical mechanism to coerce the carrier into continuing or aborting a pregnancy (if a woman aborts outside the legal limits she can face criminal sanctions; in the the case of surrogacy, even if the surrogate aborts in accordance with the existing legal provisions, she still can face some consequences under contract law, because she will be breaching the surrogacy contract and might have to pay compensation to the contracting parents); nor can the contracting parents be forced to receive a child they do not want. The consequences for failure to perform are legally provided for under contract law: first, there may be monetary amounts to be returned by the defaulting party (usually by the surrogate to the contracting parents) because they were paid in reliance on the contract being fulfilled; second, the complying party is entitled to receive compensation. The damages are more easily calculated when there is a welldrafted surrogacy contract, hence, the contract's content and its drafting assume relevance (Perdue, 2011). But the judicial enforcement of this contract, as provided in contract law, is generally not possible in surrogacy.

However, in the surrogate's case there is a scenario in which the contract can be enforced, even against her will: the mandatory delivery of the child to the contracting parents. The content of Law n.32/2006 - namely, the dissociation between gestational and genetic contribution and the fact that the contracting parents are, under all circumstances, considered to be the legal father and mother-seems to prevent the surrogate from keeping the child. Thus, if there is a court order requiring the surrogate to deliver the child to the contracting parents it seems that it must be complied with, even by force, as any other court order would be, because there is no special provision in this regard. It may be the case that courts refuse to issue such orders, but the fact is that Law n.32/2006 does not provide juridical grounds for this hypothetical right to regret.

\section{THE MAIN CRITICISMS OF THE EXISTING LAW}

One of the limitations that can be pointed to in the existing law is its scope, because surrogacy arrangements have been allowed only under very restrictive scenarios: the absence of an uterus or serious uterine lesions or disease (nonetheless, some of the projects presented for discussion were even more restrictive: Project 138/XII, from the Social-Democratic Party, only allowed surrogacy arrangements when the woman was born without a uterus). The law also includes a kind of open clause: 'justifiable clinical conditions'. This is a wiser solution than to exhaustively specify the situations allowed. However, the question arises: what can be considered a justifiable situation? For instance, is being postmenopausal a clinically justifiable situation? Age is certainly an obstacle to reproduction derived from biological conditions. In effect, age affects the ability to carry a pregnancy, due to uterine fibroids, thyroid conditions or even recurrent miscarriages. However, can it be considered 'clinical' and 'justifiable'? Or, alternatively, is the adjective 'clinical' intended to describe obstacles to reproduction derived from diseases, a classification that does not suit menopause? The fact is that in Portugal private clinics have always accepted older female patients that could not become pregnant precisely because of their age. In public hospitals the situation is different, because the National Health Service only provides reproductive treatments to younger women, supposedly taking into consideration the success rate of these treatments. In other words, because we are dealing with public resources, that are always scarce, the lawmakers have decided to pay only for treatments that guarantee a reasonable level of success. But in private facilities this limitation is not applicable and they frequently use ART in older patients because age was considered a type of infertility in the context of Article 4. This norm used to only allow ART treatments in cases of infertility or where there was a risk of transmitting a serious genetic or hereditary condition. However, nowadays it has a different content and states that ART can also be used to facilitate reproduction in the absence of a male partner. Therefore, Article 4 has now a number 3 in which it is stated that ART techniques can be used by every woman, regardless of whether there is an infertility diagnosis or the risk of transmitting a disease. Thus, the above-mentioned requisites are only valid for heterosexual couples. Evaluating the existence of 'clinical justifiable situations' has been designated a task 
for the CNPMA. This solution has raised some criticism, especially from the Bar Association, that has alleged that the CNPMA is not entitled to solely decide such a decisive matter, which should ultimately be decided by the courts.

Still another objectionable issue is the total lack of allusion to the child's best interest, usually a critical matter in the regulation of surrogacy (Lewis, 2013). Probably the reason for the legal disregard of this criterion is the fact that under Portuguese law surrogacy is strictly a contractual matter and not a conflict between filiation claims. In consequence, any case to be discussed in court will be analysed as a contract breach and not as a child custody dispute, whereas it only makes sense to invoke the child's best interests in custody disputes.

The criminalisation of surrogacy has also been one of the main targets of criticism. Surrogacy was already criminalised under the previous legal regime, a criminalisation that has persisted, although in clearer terms. Nonetheless, the main problem has not been that the law is dubious, but that criminalisation in itself is inappropriate. Indeed, there is no legal value to be protected by designating surrogacy as a crime, and consequently there are no legal grounds for construing it as a crime (Sousa, 2007). Some scholars have said that the norm protects human dignity, and they have tried to qualify it as a juridical value to be protected by criminal law. However, this qualification does not suit human dignity, which is the grounds for every single juridical value but is not in itself a juridical value, due to its vagueness and abstraction, as it was underlined by Prof. Faria Costa, in the Report presented by the Superior Council of Magistracy about one of the previous drafts of this law (Conselho Superior de Magistratura, 2012). Thus, the crime of entering into surrogacy arrangements cannot be based on the protection of human dignity. What is at stake here is the contractualization of gestation being considered immoral. However, criminal law cannot be used to protect morals and this basic principle of criminal law deprives the crime in question of a proper legal basis. In this sense the new version of the law is even more censurable because it expands the scope of criminalisation to include some cases of non-paid contracts.

The greatest weakness of this law, however, is that it does not address many of the relevant issues. In fact, although contractual freedom certainly plays an important role in surrogacy arrangements, the legislators should have had a stronger intervention, as it happens in every other contract in which there is the risk of the dominant party abusing the weaker one (see, for instance, the case with labour contracts, which obviously, et pout cause, count with a very detailed legal regulation) (Stehr, 2012).

\section{THE ISSUES OMITTED FROM THE LAW}

The Portuguese law on surrogacy does not provide any regulation regarding the surrogacy contract's content. Of course, contractual freedom plays an important role in this regard and the success of the arrangement largely depends on vesting the parties with the power to decide which clauses will rule their relationship. In any event, the clauses included in the surrogacy contract are subject to judicial scrutiny to avoid abuses, and the law is still required to establish some fundamental rules and limitations to be respected by the parties. Otherwise, chances are that one of the parties will end up dominating the other (Raposo, 2011).

\section{V.1. Abortion decisions}

Portuguese law allows the lawful termination of pregnancy under the circumstances specified in Article 142/1 of the Penal Code (PC): a) when abortion is the only means of removing the danger of death or serious and irreversible injury to the body or the physical or mental health of the pregnant woman; b) when abortion is indicated to avoid the danger of death or of serious and lasting injury to the body or the physical or mental health of the pregnant woman and it is performed within the first 12 weeks of a pregnancy; c) when there are strong reasons to predict that the unborn child will suffer from an incurable and serious illness or a serious congenital malformation, and the abortion is performed within the first 24 weeks of pregnancy, with the exception of non-viable foetuses, in which case the interruption can be carried out at any time; d) when pregnancy has resulted from a sex crime (in the words of the Portuguese Penal Code, a crime against freedom and sexual self-determination) and the interruption is performed within the first 16 weeks; and e) when the woman asks to have an abortion performed within the first 10 weeks of pregnancy, even without any further justification for such a request.

These different reasons for having a lawful abortion can be used by the surrogate and are solely dependent on her decision, because according to the law the carrier is the only person who can make decisions regarding abortion. The answer might be different if Article 142 of the Penal Code used the expression 'mother' to identity the person entitled to decide, because in surrogacy arrangements the 'mother' is the female member of the contracting couple. However, this has not been the case, and actually Article 142 of the Penal Code has always used the expression, 'the pregnant woman' or simply 'the woman', obviously referring to the carrier.

Even though Article $8 / 7$ says that the baby is considered the contracting parents' child, the fact is that before delivery this is not really the case. The surrogate has autonomy to abort, just as any other carrier would. The only difference is that in this particular scenario the surrogate could be asked to pay the contracting parents compensation for an unlawful abortion, in other words, for a pregnancy termination that complied with criminal law but was done in violation of the surrogate's contractual obligations and the contracting parents' desires.

The tricky part is that Article $8 / 10$ encourages the contracting parties to set some rules regarding abortion in the contract beforehand. However, it is undetermined just how far the contract can go in this regard. Can the contracting parents include a clause forcing the surrogate to abort in case the prenatal diagnosis detects a severe malformation or disease attacking the unborn (Forman, 2015), or simply because they are no longer interested in keeping the arrangement and they are still within the 10 week window for having a lawful abortion? The facts is that there is no scenario in which a surrogate can be forced to abort, not even by the genetic parents, for the simple reason that the unborn is 'living' inside the surrogate's body. It could not be otherwise, given that abortion must be decided by the pregnant woman, even though this basic and unquestionable rule assumes that she is also the one genetically connected to the child. So, no clause included in the contract in this regard can be used to force the surrogate to abort.

There is, however, another possible scenario: one in which the surrogate wants to abort, disregarding the contracting parents' wishes and the contract's terms. Because of her contractual obligations the surrogate should not be allowed to abort the child, unless there is a serious risk to her physical and mental health or to her life (Costa \& Lima, 2012). Nonetheless, once again, how can she be prevented from doing so and be forced to continue with the pregnancy? Of course, whenever abortion does not correspond to any of the specific scenarios foreseen in criminal law, the carrier is placed at risk of a criminal 
conviction. Moreover, even if it is lawful, the carrier could be liable for violating the contract, with legal consequences.

In sum, surrogacy contracts can, and actually should, include some arrangements for abortion, with the aim of moderating the participants' expectations and hopefully avoiding litigation, on the one hand; and of identifying the obligations that must be complied with and the damages to be compensated, on the other. The objective of Article $8 / 10$, recommending that such clauses be drafted, was precisely to emphasise that non-compliance with them can place a surrogate in default under contract law. However, at the end of the day none of those clauses can be enforced because the last word always rests with the surrogate, and the best the contracting parents can envisage is compensation for damages, which obviously is insufficient to cover their multiple losses, especially those of a nonpatrimonial nature. Thus, the payment of compensation, and even the penalty clauses in a contract, are primarily intended to motivate the surrogate to comply with her contractual obligations.

However, this conclusion faces two important obstacles.

The first is the relationship between abortion and compensation. In effect, there is an issue regarding whether the decision to abort or not to abort can lead to the payment of compensation to anyone. There is no mention of this in the legal framework regarding gestation derived from sexual intercourse, even in relation to the genetic father (I am referring to cases in which the carrier - also the genetic mother - makes a decision about the continuation of a pregnancy that goes against the genetic father's wishes). However, surrogacy differs from these other scenarios because there is a contract with inherent obligations, and this specificity may be sufficient to ground a compensation. Whenever compensation for damages is admitted, a distinction should be drawn between the cases in which the surrogate aborts against the contracting parents' wishes and the ones in which the surrogate maintains a pregnancy against the parents' decision. In the first scenario the contracting parents can be compensated for their patrimonial losses and for moral damages, but in the second only patrimonial losses should be compensated. This is not to say that in some of those situations the contacting parents do not suffer moral damage caused by the birth of a child they would prefer was not born; nonetheless, these kinds of damages have no legal support because rendering someone liable for not having aborted a child goes against the intrinsic legal value of every human life, even unborn human life.

The other obstacle to the previously mentioned conclusion relates to Article $8 / 11$, a provision that states that a surrogacy contract cannot include clauses restricting the surrogate's behaviour, or impose any restrictions undermining her rights, freedom and dignity. In this context no contract can be sustained if it stipulates impositions or prohibitions to abort, not even with the surrogate's agreement (Raposo, 2011; Forman, 2015).

\section{V.2. Clauses regarding the surrogate's duties and}

\section{limitations}

Law n.32/2006 is contradictory. On the one hand, Article $8 / 10$ imposes the inclusion of clauses related to abortion, so it seems a surrogate can suffer limitations in her abortion decisions. On the other hand, Article 8/10 forbids any clause limiting a surrogate's behaviour or weakening her rights. Must we therefore conclude that all of these clauses, except those related to abortion, are banned? This would clearly be nonsensical, since the clauses pertaining to abortion are much more restrictive than some of the other clauses that might affect the surrogate's behaviour.
Actually, Article $8 / 11$ is a very problematic provision because its real intent is far from clear. Based on a textual interpretation, it bans many of the clauses that are common in this kind of contract. For instance, it is very typical to include in surrogacy agreements a clause forbidding the surrogate from having unprotected sexual intercourse during the treatment period, in order to prevent the gestation of a child biologically related to the surrogate and her sex partner. Additionally, there are other clauses that frequently appear in these contracts, such as those aimed at preventing a surrogate from adopting behaviour that places the unborn at risk, such as alcohol or drug abuse, poor diet, non-attendance at medical appointments and practicing risky sports. This is especially problematic in terms of medical follow up, including all of the medical exams and treatments that should be undertaken during pregnancy. Can parents force their surrogate to undertake certain types of prenatal tests (for instance amniocentesis)? Can the surrogate refuse medical treatment during pregnancy that may jeopardise the unborn child's current and future health? Every one of these clauses seems to violate the ban imposed by Article 8/11.

Article $8 / 11$ has two parts, both of which are poorly drafted. In the second part the statute bans any clause that (in the law's own words): "attemps against her [the norm is referring to the surrogate] rights, freedoms and guarantees'. It is unclear if the verb 'attempts' means 'violates' or simply 'restricts'. The former interpretation would allow the drafting of clauses that although limiting the surrogate's rights do not lead to a violation, because they are justified in a particular situation. However, even if this interpretation prevails, there is still the obstacle raised by the first part of the Article, and this one is apparently insurmountable. In effect, the first part states that the contract cannot 'impose restrictions on the surrogate's conduct'. The legislators could have used a more selfconfined expression, such as 'restricts the surrogate's conduct in an unlawful way' or 'without justification', but they opted instead to use a broad formula. This is obviously very problematic in terms of a contract's content, because such a general formulation includes almost every clause. Thus, in light to the law' text we have to conclude in favour of prohibiting all of the above-mentioned clauses, unless courts moderate the lawmakers' impetus and only exclude abusive clauses that severely impair the surrogate's rights and the basic power to control her own body.

Despite these limitations, the contracting parents can still go to court and argue breach of contract in a case where a child is born with severe injuries resulting from the surrogate's behaviour (although in some cases it may be difficult to establish a causal connection).

But the legal prohibition imposed by Article $8 / 11$ prevents the contracting parents from going to court to request a writ of prohibition at the commencement of a surrogate's risky behaviour, which could prevent such conduct (although it could be debated whether the court could force the surrogate, or any person for that matter, to behave in a certain way regarding this kind of personal situation), precisely because the contract cannot contain most of the clauses imposing or forbidding the surrogate's behaviour. Thus, in this instance breach of contract cannot be argued. The legal basis is lacking to prevent the child's potential injury and the contracting parents must wait until the child's birth to determine if severe injury has resulted from the surrogate's reckless behaviour, so they can ask for compensation.

Law n.32/2006 is also silent on cases in which the child is expected to have a genetic bond with the contracting male, who was the intended sperm provider, but instead is the child of the surrogate's sex partner. Under the provisions 
of Article 8/11, a surrogacy contract cannot contain a clause forbidding a surrogate to have unprotected sexual intercourse, even for a limited period of time. Therefore, the contracting parents cannot invoke breach of contract under this scenario. However, even if this particular clause is forbidden, the contracting parents are not required to accept the child if it does not have any genetic bond with either of them. The problem is that Article $8 / 7$ does not include any caveat in this regard, apparently considering the contracting parents to be the legal parents, even in those cases in which the expected (and contracted for) genetic connection with the child does not exist due to the surrogate's sexual misconduct (the question that may arise is a potential paternity demand from the genetic father, in this case, the surrogate's sex partner).

\section{V.3. Embryo transfer}

The legislators have not addressed the issue of how many embryos can be transferred to the surrogate's uterus within a surrogacy arrangement. However, in the particular case of the Portuguese regulation this is not a decisive omission because, as a general rule, for every uterine transfer it is understood that the doctor makes that decision. In effect, Article 24 states that with in vitro fertilisation procedures the medical team will only create the number of embryos considered necessary for the success of the treatment, taking into consideration good clinical practice and the patient's informed consent (n.1); and further, that the number of oocytes to be fertilised must be based on the patient's clinical situation and the prevention of multiple pregnancies (n.2). Although the Article only seems to refer to the number of eggs to be fertilised (n.2) and the embryos to be created (n.1), which are actually the same thing, it is commonly interpreted as also referring to the number of embryos to be transferred (even though the legislators have not addressed the issue in the above mentioned regulations). The beneficiaries of the techniques (the expression that the law uses to refer those using ART) are listened to and it can be assumed that in this situation both the surrogate and the contracting parents are heard, although the actual informed consent must be provided by the surrogate, who is the beneficiary of the techniques in this regard. The final decision still belongs to the medical team and hence clauses included in the contract in this regard are almost useless.

\section{V.4. Requisites regarding the surrogate}

Another issue also waiting to be clarified by lawmakers is who can become a surrogate. The only rule in this respect is Article 8 (6), which prevents surrogacy by an individual in a position of economic subordination with one or both of the contracting parents. Some previous drafts required a kinship relationship between the parties; however, this requirement disappeared in the final version, which was obviously a wiser option, given that if the surrogate was a relative she would be submitted to even greater pressure than might exist in the aforementioned relationship of economic subordination.

The law says nothing more. It does not even deal with the surrogate's age. In this respect, we can apply Article $6 / 2$, according to which 'techniques can only be used for the benefit of those who are at least 18 years of age and not prohibited or disabled by psychic anomaly'. However, this is an application by analogy, because the law refers to the beneficiaries of the techniques.

Furthermore, the law should have imposed certain requirements, such as having sufficient emotional maturity (majority is not enough) and the existence of previous children, so the surrogate could understand the kind of emotional experience and connection that gestation involves (Cascão, 2016). In any case, the surrogate should be subjected to physiological and physical evaluation before entering into the surrogacy arrangement: the former to assess her capacity to cope with the emotional challenges of the surrogacy contract; and the latter to evaluate whether she is physically able to carry on with the pregnancy and to check whether she carries any genetic conditions transmissible by gestation.

The law should also impose regular emotional and legal counselling on both parties, provided in an independent way, especially with regard to legal counselling (Cascão, 2016).

V.5. Payment and compensation of the surrogate Another question requiring further clarification is the possibility of compensation for the surrogate. The law very firmly bans any kind of payment or the donation of any commodity to the surrogate, and only allows reimbursement for certified health expenses, including transportation. The law says nothing about lost income due to absences from work due to the pregnancy, although surely these are also expenses that deserve reimbursement.

Further, the law is silent on compensation for the surrogate's inconvenience. According to numbers 2 and 5 of Article 8 , surrogacy contracts cannot involve any payment. However, the same prohibition has prevailed in other contracts (for instance, in gamete donation contracts: Article 18) and subsequently another law has allowed compensation for inconvenience (Article 22/3 of Lawn. 12/2009, from 26 March, the legal regime pertaining to quality and safety in the processing of human tissues and cells).

Still another issue that must be resolved by the legislators is who should bear the financial responsibility for any disability or health condition caused to the surrogate as a result of gestation. In this regard the law should have imposed an obligation to contract for health and life insurance for the surrogate in case she ends up suffering injuries from the pregnancy or delivery or even dies (Cascão, 2016).

\section{V.6. The territorial scope of the law}

The law does not clarify whether the parties - the contracting parents and the surrogate - must be Portuguese citizens or at least reside in Portugal. Given the current relevance of reproductive tourism and the movement of people in search of the best legal order to conclude a surrogacy arrangement (Deonandan, 2015), this is a matter of major importance. However, the law does not contain any requirement as to the residency and/or nationality of the contracting parties, nor any clarification as to the possible legal validity of a contract concluded in Portugal and in light of Portuguese law by persons who come to Portugal specifically for this purpose.

Based on the legal silence it can be sustained that the provisions of the law can be used by foreign people, even if they do not maintain regular residence in Portugal.

Undoubtedly, this will raise several problems in terms of international private law, namely regarding the recognition of the surrogacy contract by other legal orders and the consequent recognition of filiation arrangements, as they are established by Law n.32/2006.

\section{CONCLUSION}

The characteristics that distinguish the new Portuguese surrogacy law are basically three: the lack of regulation regarding the contract's content; the ban of pretty much 
every clause restricting the surrogate's behaviour; and the absence of a legal right to regret.

Regarding the first trait, Portuguese lawmakers have decided to remain silent on most aspects of the contract's content and due to this passivity have left some problems to be resolved by the parties (eventually with little success), or later on by the courts.

With respect to the prohibition of restrictive clauses, Article $8 / 11$ is very ambiguous regarding its real meaning and it will be up to the courts to interpret it, hopefully in a more flexible way than its apparent legislative intent. If every single clause ends up being forbidden it will jeopardise the aims of the surrogacy contract and seriously threaten the child's well-being.

As for the lack of an express provision regarding the right to regret, it seems to imply that any decision by the parties to be released from the contract will be considered a breach, leading to legal consequences under contract law. At the moment, it cannot be predicted how the 'breach' will be evaluated by the courts, namely whether contract liability rules will prevail. It seems the only circumstance in which the contract can be enforced against the will of one of the parties is when, after delivery, the surrogate refuses to deliver the child and the contracting parents still want the child and demand that the contract be fully executed. However, even in that scenario it is doubtful whether the judges will rule on the contract's execution.

At the moment, without any court decisions or any other clarification from the CNPMA, the interpretation of this law is still very unclear. I believe that although the approval of this legal regime represents a laudable effort to enforce the right to reproduce and the right to create a family by those who cannot do so by themselves, the fact is that it raises as much doubt as criticism, mainly due to its silence on many issues requiring regulation.

\section{CONFLICT OF INTERESTS}

The authors have no conflicts of interest to report.

\author{
Corresponding author: \\ Vera Lúcia Raposo \\ Faculty of Law \\ Macao University, \\ Macao, China \\ E-mail: vera@fd.uc.pt
}

\section{REFERENCES}

Antunes MJ. Procriação medicamente assistida: Questões novas ou questões renovadas para o direito penal. In: Andrade MC, Antunes MJ, Sousa SA, eds. Estudos em homenagem ao Professor Doutor Jorge de Figueiredo Dias. Coimbra: Coimbra Editora; 2009. p. 81-112.

Appleton SF. Reproduction and regret. Yale J Law Fem. 2011;23:255-333.

Araújo F. A procriação assistida e o problema da santidade da vida. Coimbra: Almedina; 1999.

Ascensão JO. A Lei n. ${ }^{\circ}$ 32/06, sobre procriação medicamente assistida. Revista da Ordem dos Advogados. 2007; 67III. Available at: https://portal. oa.pt/comunicacao/publicacoes/revista/ano-2007/ano67-vol-iii-dez-2007/doutrina/jose-de-oliveira-ascensaoa-lei-n\%C2\%BA-3206-sobre-procriacao-medicamenteassistida/. Accessed: 4/7/2017.
Cascão R. The challenges of international commercial surrogacy: From paternalism towards realism? Med Law. 2016;35:151-64.

CNPMA (Conselho Nacional de Ética para as Ciências da Vida). Declaração interpretativa (n. 1 do artigo 30 da Lei n. ${ }^{3} 32 / 2006$, de 26 de Julho, alterada pelas Leis n. ${ }^{\circ}$ 17/2016, de 20 de Junho, e 25/2016, de 22 de Agosto), Setembro 2016. Available at: http://www.cnpma.org. pt/Docs/CNPMA_DeclaracaoInterpretativa_SET2016.pdf. Accessed: 4/7/2017.

Conselho Superior de Magistratura. Pareceres referentes aos projectos de Lei $131 / X I I / 1^{a}$ (PS); $137 / X I I / 1^{a}$ (PS); $122 / X I I / 1^{a}$ (BE); 138/XII/1a (PSD) e 173/XII/1a, document issued at 21.03.2012.

Costa M, Lima C. A maternidade de substituição à luz dos direitos fundamentais de personalidade. Lusíada. 2012;2:237-89.

Deonandan R. Recent trends in reproductive tourism and international surrogacy: Ethical considerations and challenges for policy. Risk Manag Healthc Policy. 2015;8:111-9. PMID: 26316832 DOI: $10.2147 /$ RMHP.S63862

Dias AS. Ramos Emergentes do direito penal relacionados com a protecção do futuro (Ambiente, consumo e genética humana). Coimbra: Coimbra Editora; 2008.

Forman DL. Abortion clauses in surrogacy contracts: Insights from a Case Study. Fam Law Q. 2015;49:29-53.

Lewis BC. Due date: Enforcing surrogacy promises in the best interest of the child. St Johns Law Rev. 2013;87:899952.

Oliveira G. Mãe há só uma (duas)! O contrato de gestação. Coimbra: Coimbra Editora; 1992.

Perdue AL. For love or money: an analysis of the contractual regulation of reproductive surrogacy. J Contemp Health Law Policy. 2011;27:279-313. PMID: 21675433

Raposo VL. Em Nome do Pai (Da mãe, dos dois pais, e das duas mães) - Análise do art. $6^{\circ}$ da Lei 32/2006. Lex Medicinae. 2007;4:37-51.

Raposo VL. A idade da inocência: Podem os contratos de gestação sobreviver sem lei reguladora? Rev Jurídica UNISEB. 2011;1:143-72.

Raposo VL. O direito à imortalidade (o exercício de direitos reprodutivos mediante técnicas de reprodução assistida e o estatuto jurídico do embrião in vitro. Coimbra: Almedina; 2014.

Reis RV. Erro na crasso na maternidade de substituição. O Público. 2016 Jul 7. Available at: https://www. publico.pt/2016/07/20/sociedade/noticia/erro-crassona-maternidade-de-substituicao-1738773. Accessed: 4/7/2017.

Reis RV. Responsabilidade penal na procriação medicamente assistida - A criminalização do recurso à maternidade de substituição e outras soluções criminalmente duvidosas. Lex Medicinae. 2010;7:69-93. 
Sousa SA. Sobre o bem jurídico protegido nos crimes contra a humanidade. Bol Fac Dir Univ Coimbra. 2007;83:615-37.
Stehr E. International surrogacy contract regulation: national governments' and international bodies' misguided quests to prevent exploitation. Hastings Int Comp Law Rev. 2012;35:253-87. 